\title{
Sveti Ćiril i Metod i prijevod Svetog pisma na crkvenoslavenski jezik
}

\author{
Taras Barščevski*
}

\begin{abstract}
Sažetak
Temeljni je razlog nastajanja nekog prijevoda ponajprije omogućiti razumijevanje originalnog teksta onomu tko ne razumije jezik na kojem je taj tekst napisan. Biblijski tekstovi nisu samo tekstovi napisani na starohebrejskom (i aramejskom) ili starogrčkom jeziku, nego oni sadržavaju i Riječ Božju — objavu Boga o Sebi te Njegove volje spasenja za svakog čovjeka. Dakle, prijevod Svetog pisma nije samo prijevod s jednog jezika (drevnog $i$ nerazumljivog) na drugi jezik (moderan i razumljiv), nego i prenošenje Božanske Objave. Prijevod sv. Cirila i Metoda realizira i jedno i drugo. Članak istražuje preduvjete i nastajanje ćirilometodskog prijevoda Svetog pisma na slavenski jezik, uzimajući u obzir ponajprije razloge - naviještaj Evanđelja kod Slavena, no i poteškoće tog prijevoda - nepostojanje pisma i otpor slavenskomu jeziku u liturgijskoj upotrebi. Odgovor Slavenskih apostola na nepostojanje slavenskog pisma bilo je stvaranje glagoljice i ćirilice, a pravo na liturgijsku upotrebu bilo je ostvareno prijevodom ne samo Svetog pisma, nego i brojnim liturgijskim tekstovima. No ta dostignuća Svete braće imala su utjecaj ne samo na razvoj kršćanstva kod slavenskih naroda u početcima, nego su u kasnijim stoljećima često postajala i razlog zastoja misijske gorljivosti radi očuvanja „sakralnosti“ slova prijevoda.

Ključne riječi: Prijevod Svetog pisma, sv. Ćiril i Metod, crkvenoslavenski jezik, glagoljica, ćirilica, „sakralnost“ prijevoda
\end{abstract}

\section{Uvod $^{1}$}

Zašto postoje prijevodi Svetoga pisma? Na to banalno pitanje moglo bi se jednostavno odgovoriti: Zato da bi današnji čovjek, koji ne poznaje ni starohebrejski ni starogrčki, mogao čitati i razumjeti Sveto pismo. No zašto onda postoje tako

* Dr. sc. Taras Barščevski, Katolički bogoslovni fakultet Sveučilišta u Zagrebu. Adresa: Vlaška 38, p.p. 432, 10000 Zagreb. E pošta: tbarscevski@kbf.hr

1 Ovaj rad je nastao kao samostalan članak s novom impostacijom i zaključkom na temelju neobjavljenog dijela doktorskog rada La traduzione della Sacra Scrittura in lingua ucraina, Rim: Papinsko salezijansko sveučilište, 2014. Osim toga, dopunjen je i bibliografijom na hrvatskom jeziku. 
brojni i različiti prijevodi?2 I ne samo to, nego i danas se nastavlja s izdavanjem ranijih prijevoda (često ispravljena u različitim formatima ili u „novom ruhu“ $s$ bilješkama) ${ }^{3}$ ili se započinju novi projekti prijevoda Biblije. ${ }^{4}$ Moglo bi se odgovoriti da je osnovni razlog u razvoju jezika, zbog čega su čak nekad jasni prijevodi danas postali teško razumljivi, a također zbog razvoja biblijskih znanosti koje nam daju mogućnost puno bolje razumjeti biblijski tekst od naših prethodnika. Bi li to značilo da su suvremeni prijevodi kvalitetniji od onih iz prošlosti? U puno čemu može se reći da jesu. Uostalom, kakav bi bio smisao stvarati lošiji prijevod? Zahvaljujući razvoju biblijskih znanosti i zaista brojnim egzegetskim radovima, danas možemo reći puno više o značenju neke riječi, izraza, gramatičke ili sintaktičke strukture, otkrivajući smisao aluzija, igri riječi, skrivenih značenja, nego su to mogli učiniti naši prethodnici. No prijevod ne može biti sveden samo na opširniju i točniju informaciju o tekstu (bez obzira na to je li riječ o većoj cjelini ili o najsitnijem detalju) ili na njegovo bolje razumijevanje, nego uključuje i prijenos značenja teksta, tj. učinak na čitatelja. I to nas vraća novoj valorizaciji davnih prijevoda, a pogotovo onih koji su bili prvi prijevodi na neki novi jezik, donoseći novim adresatima ne samo biblijsku kulturu, nego prije svega Riječ Božju i novi život u Kristu! Jedan od takvih prijevoda, možda i najvažniji za naše kulturnocrkveno područje je prijevod sv. Ćirila i Metoda, koji je nastao još u 9. stoljeću i zahvaljujući kojemu su mnogi slavenski narodi upoznali Riječ Božju.

\section{Sv. Ćiril i Metod ${ }^{5}$}

Sveto pismo je u crkvenoslavenskom prijevodu ušlo u slavenski svijet zahvaljujući misijskom i evangelizacijskom djelu sv. Ćirila i Metoda te je povezano s njihovom misijom u Moravskoj. Izvještaji o njihovoj moravskoj misiji dolaze nam iz dva hagiografska izvora: Vita Constantini i Vita Methodii. ${ }^{6}$ Iako su oba djela

2 Dovoljno bi bilo samo pogledati neke članke kako bismo shvatili koliko su brojni biblijski prijevodi i izdanja Svetog pisma na hrvatski jezik: Štefanić, 1941; Fućak, 1991; Vojnović, 2006; Jambrek, 2007; Jambrek i Knežević, 2007.

3 Primjerice Jeruzalemska Biblija s velikim komentarom iz 1994. i bez straničnih bilježaka iz 2008., ili Ekumenska biblija s uvodima i bilješkama iz francuskog izdanja Ekumenskog prijevoda Biblije - TOB (NZ - 1992.; SZ - 2011.).

4 Primjerice Novi prijevod Biblije, koji je pokrenulo Hrvatsko biblijsko društvo, i čiji se završetak predviđa za kraj 2018. godine.

5 Godina je 1985. povodom 1100. obljetnice smrti sv. Metoda bila obilježena u Hrvatskoj kao „Metodova godina" (Suljak, 1986). Uz brojne proslave, svečanosti i simpozije diljem domovine u tisku su se pojavili vrijedni radovi na hrvatskom jeziku o slavenskim prosvjetiteljima sv. Ćirilu i Metodu, kao primjerice: Grivec, 1985; Bajsić, 1985. Posebnu pažnju zaslužuje članak isusovca Michala Lacka (Lacko, 1985-1986), koji je objavljen u sklopu strip-izdanja Kršćanske sadašnjosti: Devlić i dr., 1985-1986, te također članak V. Štefanića, koji je već 1963. pisao o Tisuću i sto godina od Moravske misije: Štefanić, 1963. Između ostalih veoma brojnih radova na ćirilometodsku problematiku naveo bih ovdje samo one koji tematski više nadopunjuju ovaj članak: Bratulić, 1991; Grabar, 1986; Šanjek, 1983; Damjanović, 2013; Damjanović, 2015; Lukić, 2011.

6 Jedno od najstarijih istraživanja, zahvaljujući kojima su ti životopisi svetih postali poznati, napisao je Aleksandar V. Gorski (1843). Kritičko izdanje slavenskog teksta oba životopisa s pri- 
nastala u dosta kratkom razdoblju, nakon opisanih događaja i sadržavaju detalje, koje nalazimo također i u Legenda italica, ${ }^{7}$ ipak sadržavaju i probleme zbog nekih netočnosti u tekstu i malog broja rukopisa, no ponajviše zbog dosta kasne kompozicije rukopisa koje imamo. ${ }^{8}$

Prema tim životopisima, dva brata, Metod i Ćiril, rodili su se u Solunu (Makedonija), drugom po veličini gradu Bizantskog Carstva. Metod se rodio 815. godine, a njegov mlađi brat, nazvan na krštenju Konstantin, 826. ili 827. godine. Njihov otac Lav bio je drungar — visoki bizantski vojni zapovjednik. U njihovom rodnom gradu u to je vrijeme živio velik broj Slavena, pa su oba brata bila upoznata sa slavenskim jezikom od djetinjstva. Još u ranoj mladosti Konstantin je otišao u Carigrad, gdje je završio studije filozofije i teologije. Zaređen je za svećenika, postao je kasnije i bibliotekar knjižnice Svete Sofije te učitelj filozofije i teologije. Putovao je na Istok radi važnih diplomatskih zadaća u muslimanskom svijetu. U Carigradu je upoznao Focija, koji je 858. godine, zahvaljujući kraljici Teodori, postao carigradskim patrijarhom.

\subsection{Hazarska misija $i$ rus'ska slova}

Oko 860./861. zajedno sa svojim bratom Metodom Konstantin je bio poslan u Kijevsku Rus's misijom Hazarima — konfederaciji nomadskih turkijskih plemena, koji su se krajem 8. i početkom 9. stoljeća obratili na židovstvo i koji su živjeli na prostorima koji su se prostirali od Crnog mora do Kaspijskog jezera. Na svojem putovanju u Hazarski kanat braća su se nekoliko mjeseci zadržala u Hersonu, koji je tada bio u sklopu Bizantskog Carstva. Govori se da je Konstantin za vrijeme boravka u Hersonu (Vita Constantini, VIII) naučio hebrejski jezik, pripremajući se tako za diskusije s učenim židovima s tih područja. Konstantinov biograf primjećuje također da je poslije diskusije sa Samarijancima Konstantin tako dobro izučio jezik da je mogao čitati i samarijanske knjige (očigledno Stari zavjet). Kako treba shvaćati ta Konstantinova jezična postignuća ostaje i dalje diskutabilno. U svakom slučaju Translatio je puno diskretniji i govori o samo jednom jeziku, kojeg je naučio Konstantin u Hersonu — hazarskom.

jevodom na latinski jezik nalazimo u: Grivec i Tomšič, 1960. Hrvatski prijevod tih životopisa s tumačenjima uredio je Josip Bratulić (1985).

7 Legenda italica, poznata također kao Vita cum Translatione S. Clementis ili jednostavno Translatio, pripovijest je na latinskom jeziku o pronalaženju relikvija sv. Klementa, koji je, prema pripovijesti, bio primoran za vrijeme kraljevanja Trajana otići u izgnanstvo na Krim na rad u rudnicima. Datirana je najkasnije u prvu polovicu 879. godine.

8 Prema dosadašnjim istraživanjima postoje 32 rukopisa Vita Constantini, od kojih su najstariji: 1) Codex Academiae Theologicae (Duhovnaja Akademija) Moscoviensis iz prve polovice 15. stoljeća; 2) Codex monasterii s. Onuphrii Leopoli (Lavov, Ukrajina) iz druge polovice 15. stoljeća; 3) Rukopis Vladislava Gramatika napisan 1469. u manastiru sv. Bogorodice u Žegligovu (Makedonija) i 4) još jedan rukopis Vladislava Gramatika iz 1479. Od Vita Methodii postoji samo osam rukopisa, od kojih je najstariji rukopis iz kolekcije Uspenskog Sobora iz Moskve, koji potječe iz 12. stoljeća (Grivec i Tomšič, 1960, 16-17, 20). Tako da je naš tekst Vita Constantini udaljen od originala najmanje 300 godina, a tekst Vita Methodii - petsto godina prepisivanja i izdavanja. 
Autor Vita Constantini tvrdi također da je Konstantin u Hersonu »našao [rukopis] Evanđelja i Psaltira, napisan rus'skim slovima i jednog čovjeka koji je govorio tim jezikom «. ${ }^{9}$ Budući da nemamo točnih podataka o razvoju literature kod Slavena prije Konstantina i Metoda, taj podatak o jednoj epizodi iz života sv. Konstantina otvorio je put različitim pretpostavkama (Metzger, 1977, 397). ${ }^{10}$ Neki smatraju da je riječ o gotičkom pismu (Vasiliev, 1936, 113s). ${ }^{11}$ Ostali smatraju da je riječ o pismu koje sadržava mješavinu armenskih i gruzijskih slova prilagođenom lokalnomu slavenskomu jeziku (Vernadsky, 1943, 349-450). Neki ruski slavisti, prema Grivecu i Tomšiču, misle da je riječ o ruskim slavenskim slovima (Sreznevskij, Grigorovič, Lamanskij, Nikolskij) (Grivec i Tomšič, 1960, 184). ${ }^{12}$ Te pretpostavke javljaju se na temelju mišljenja da su Slaveni već imali pismo prije Ćirila i Metoda te interpretiraju rous'ski u smislu „zapadno slavenskog“. ${ }^{13}$ Postojanje „protoćiriličnog“ pisma, koje pretpostavlja Sreznevski, a kasnije razrađuju Miller, Karski, Ohijenko i Georgiev, opširno je dokumentirao Istrina, koji smatra da su razvoj bugarske literature (kraj 9. i početak 10. stoljeća) i procvat pismenosti u svakodnevnom životu kod Slavena (10. - 11. stoljeće) dokaz postojanja protoćiriličnog pisma (Istrin, 1988, 104-105). Prema Ivanovoj već 1963. jedini je još branio tezu slavenskog podrijetla rous'skih slova iz Vita Constantini (tj. protoćirilično pismo) bugarski znanstvenik Georgiev, koji identificira narod nazvan Grcima 'P $\omega \varsigma$ s istočnim Slavenima i deducira iz čitanja rous'ski da je riječ o pismu naroda Ros (taj bi narod bili baš istočni Slaveni) (Ivanova, 1969, 72-73; Georgiev, 1966, 64).

Posljednja pretpostavka, koja izgleda prihvatljiva čak jednomu znanstveniku biblijske kritike Metzgeru (1977, 398), predlaže promjenu u čitanju te umjesto роусьскыми писмены с̌itati соурьскыми, tj. sirijskim slovima. ${ }^{14}$ Kao podrška takvomu ispravku navodi se XVI. poglavlje Vita Constantini, gdje većina rukopisa

9 Vita Constantini, VIII, 15: »Invenit vero ibi evangelium et Psalterium Rossicis litteris scripti et hominem invenit loquentem illa lingua « (Grivec i Tomšič, 1960, 184). Grivec i Tomšič u kritičkom aparatu predstavljaju sedam različitih čitanja pridjeva русьски, dajući prednost rukopisu iz samostana sv. Onufrija u Lavovu, objavljen Miklošičem, koji pripada ,južnoj porodici“ rukopisa Vita Constantini. Lavrov naprotiv izabire čitanje rukopisa koji se nalazi u knjižnici Teološke akademije u Moskvi i koji sadržava varijantu роусьскьмми $(1930,12)$.

10 Vidi također: Birnbaum, 1997-1999, 9-15.

11 Prije toga je Iljinski pretpostavio da je čitanje rous'skymi pismeny proizišlo kao posljedica obične zamjene slova za vrijeme prepisivanja originala фргжыскыми $\rightarrow$ проушккыми $\rightarrow$ роушккыми (Iljinski, 1924, 64), tj. russkie treba shvatiti u smislu franskog ili gotičkog pisma (Ivanova, 1969, 74). Da je riječ o ,gotičkom“ pismu i o „gotskom“ čovjeku, smatra i Pavel Jungerov (1902, 499-500).

12 Ili „protoglagolitički“, kako ga zove Istrin, navodeći iste autore, no smatrajući to malo vjerojatnom pretpostavkom (Istrin, 1988, 113).

13 »Bez svake sumnje treba prihvatiti da su Hersonske knjige bile napisane ne samo ruskim pismom, nego i paleoruskim jezikom. To je potvrđeno kasnijom pripoviješću Životopisa glede činjenice da je Konstantin veoma brzo naučio čitati tu knjigu, tako da su njegovi drugovi na putovanju — Grci — smatrali da se radilo o pravom čudu. Ustvari nije bilo nikakvog čuda... Konstantin (Ćiril) i njegov brat Metod bili su makedonski Slaveni te su razgovarali jezikom veoma bliskim paleoruskom« (Černih, 1951, 131).

14 Ta pretpostavka Vaillanta $(1935,75-77)$ bila je kasnije razvijena kod Jakobsona (1939-1944, 181-186). Poslije bila je prihvaćena od Lunta $(1964,271)$ i Dvornika $(1970,66)$. 
dodaje u 8. retku pycu umjesto соури (Grivec i Tomšič, 1960, 136 i 138). ${ }^{15}$ Osim toga, postoji velika vjerojatnost da su u Hersonu postojale knjige na sirijskom jeziku, barem iz tog razloga što je tada Krim pripadao crkvenoj jurisdikciji Antiohije, tj. Sirijskoj crkvi (Metzger, 1977, 398). No i sam tekst Vita Constantini, prema Ivanovoj, može nam ponuditi argumente za „sirijsko“ čitanje rous'skih slova. U VIII. poglavlju Vita Constantini kaže se da je Konstantin, stigavši u Herson, izučio hebrejski, kasnije se susreo s jednim Samarijancem, koji mu je donio samarijanske knjige, koje je Konstantin u kratkom vremenu počeo čitati bez grešaka. Tek tada se govori da je otkrio Evanđelje i Psaltir napisane rous'skima slovima. Dakle, rous'skyj, koji treba shvatiti kao sourskyj, završavao bi redoslijed: hebrejski — samarijanski — sirijski. Osim toga, da bi Konstantin naučio čitati rous'ske knjige, morao je izučiti »različita slova, samoglasnike i suglasnike«, tj. pismo koje se razlikuje od grčkog u načinu pisanja suglasnika i samoglasnika, što je karakteristično za pisma aramejskog podrijetla. Sirijski, koji ima tu zajedničku karakteristiku s hebrejskim, razlikuje se ipak od hebrejskog u samoj grafiji slova. Dakle, Konstantin, koji je naučio hebrejski i samarijanski, lako je mogao izučiti i sirijski, tim više što je sadržaj knjiga (Evanđelje i Psaltir) poznavao veoma dobro (Ivanova, 1969, 75). Sama činjenica da su Hazari, prema kojima je bila usmjerena misija Konstantina i Metoda, pripadali židovskoj vjeri, mogla bi objasniti zainteresiranost za hebrejski i samarijanski, no posebice i za sirijski — jezik istog korijena, no „kršćanski“.

\subsection{Moravska misija i obrana slavenskog prijevoda ${ }^{16}$}

Poslije misije kod Hazara Konstantin se vratio u Carigrad, uzevši sa sobom relikvije sv. Klementa, koje je pronašao u Hersonu. No glavno je djelo Konstantina i Metoda još bilo na samim početcima. Moravski je knez Rastislav poslao u Carigrad poslanike s molbom caru Mihaelu III. da mu pošalje biskupa i misionare za narod. U to vrijeme Moravska je već bila djelomice kristijanizirana zahvaljujući zapadnim misionarima, no Rastislav se želio osloboditi političkog utjecaja njemačkih biskupa jer je područje Moravske pripadalo crkvenomu nadleštvu Passau i Salzburga. Izbor je pao na Konstantina i Metoda, koji su stigli u Moravsku oko 863. godine. Prema svjedočenju Vita Constantini (XIV,13-14), prije polaska za Moravsku Konstantin je »poslije božanstvene objave sastavio pismo te počeo pisati evanđeosku riječ«, počevši od Evanđelja po Ivanu. Poslije dolaska u Moravsku (Vita Constantini, XV,1-2) Konstantin je uz pomoć Metoda preveo cijeli ирьковнии чин („crkveno pravilo“) i ostale liturgijske knjige na slavenski. Osim toga, braća su se posvetila propovijedanju i odgoju klera. Propovijedi i liturgijski obredi na jeziku kojeg je narod mogao razumjeti imali su

15 Zamjenu između $r$ is u 6. poglavlju Vita Constanini primijetio je još Jagić $(1895,291)$. Ali je tek Vaillantu to opažanje zamjene slova poslužilo kao temelj pretpostavke da umjesto rus'skog pisma treba shvatiti sirijsko pismo.

16 Ovo i sljedeće poglavlje napisani su na temelju Vita Constantini, Vita Methodii i Vita cum Translatione S. Clementis. Za staroslavenski i latinski tekst: Grivec i Tomšič, 1960; za hrvatski prijevod: Bratulić, 1985. 
velik uspjeh, no istovremeno su izazvali neprijateljstvo lokalnog klera. Braća su optužena za herezu s tvrdnjom da samo grčki, hebrejski i latinski mogu biti liturgijskim jezicima.

Na poziv pape Nikole I. (858. - 867.), poslije četiri i pol godine misijske djelatnosti u Moravskoj, ${ }^{17}$ Ćiril i Metod uputili su se u Rim, gdje ih je primio papa Hadrijan II. (867. - 872.), kojemu su poklonili relikvije sv. Klementa, donesene s putovanja Hazarima. Hadrijan II. odobrio je upotrebu slavenskog jezika u liturgiji, no pod jednim uvjetom: nedjeljna čitanja morala su prije biti na latinskom, a tek poslije na slavenskom (Vita Methodii, VIII, 13). U Rimu se Konstantin teško razbolio te je za vrijeme bolesti primio redovničke zavjete i novo ime - Ćiril. Umro je 14. veljače 869. i sahranjen je u bazilici sv. Klementa.

Poslije bratove smrti Metod, postavljen za nadbiskupa Smirne, krenuo je u Moravsku kao papinski legat. Zbog oštrog sukoba s crkvenom vlašću Bavarske (izgleda već za vrijeme svojeg putovanja iz Rima) bio je uhićen. Tek poslije dvije i pol godine, zahvaljujući intervenciji novog pape Ivana VIII. (872. — 882.), bio je oslobođen te se vratio u Moravsku. No ponovo je optužen u Rimu za herezu. Tako da se ponovo uputio u Rim, gdje je u potpunosti opravdan, a liturgija na slavenskom jeziku ponovo je potvrđena. Vrativši se u Moravsku posvetio se organizaciji i konsolidaciji crkvenog života. Umro je 6. travnja 885. godine. Poslije Metodove smrti liturgija na slavenskom jeziku ponovo je bila zabranjena u Moravskoj, a njegovi brojni učenici bili su protjerani i neki od njih čak prodani kao robovi.

Rast kulturnog života na području današnje Bugarske i Makedonije pri kraju 9. i početkom 10. stoljeća stvorio je povoljne uvjete za razvoj kršćanstva. Za vrijeme kraljevanja Simeona (893. - 927.) u Bugarskoj je došlo do procvata bugarske literature, no već pri kraju 10. stoljeća pada književna aktivnost. Novi poticaj slavenska literatura dobiva u Kijevskoj Rusi, gdje je kršćanstvo postalo službenom religijom s krštenjem kneza Vladimira 988., više od 120 godina nakon Konstantinova otkrića rus'skih slova.

\section{2. Ćirilo-Metodov prijevod Svetog pisma}

S imenima sv. Ćirila i Metoda, osim širenja kršćanstva na jednom slavenskom jeziku, povezan je također stvaranje slavenskog pisma i prvi prijevod Svetog pisma na slavenski jezik.

\subsection{Pismo Ćirilo-Metodova prijevoda}

Prema Vita Constantini (XIV, 13-14) i Legenda italica ili Vita cum Translatione S. Clementis (br. 7), prije polaska u Moravsku Konstantin je stvorio slavensko pismo te je započeo prijevod Evanđelja od - kako tvrdi Vita Constantini - »u 
početku bijaše Riječ i Riječ bijaše u Boga i Riječ bijaše Bog «. ${ }^{18}$ Nekoliko godina kasnije u spisu $O$ slovima Črnorizac Hrabar, tj. redovnik Hrabar, piše da »prije Slaveni nisu imali knjiga, nego „črtami i rezami“ crtahu i gatahu budući pogani ${ }^{19}$ Primivši krštenje, pokušali su — nastavlja Hrabar — pisati slavenske riječi rimskim (latinskim) i grčkim slovima, no bez ikakvog sustava. To stanje trajalo je duže vrijeme, sve dok se »Bog nije smilovao te je poslao svetog Konstantina Filozofa, nazvanog Ćiril, čovjeka pravedna i istinita «, koji je stvorio za Slavene 38 slova, iz kojih 24 slična grčkim, a 14 koja odgovaraju slavenskomu jeziku, zato što nije bilo moguće pisati grčkim slovima riječi koje su sadržavale tipično slavenske zvukove. Autor traktata uspoređuje postanak slavenskog pisma s poviješću grčkog, a razvoj prijevoda Svetog pisma na slavenski s prijevodom na grčki te se suprotstavlja „dogmi triju jezika“. Iz toga možemo zaključiti da je Hrabar prije svega želio dokazati zakonitost i prirodnost slavenske pismenosti (Nimčuk, 1985), njezino pravo na postojanje te pravo da posjeduje svoj vlastiti prijevod Svetog pisma.

Još jedna poteškoća o kojoj moramo govoriti je ta da crkvenoslavenski rukopisi kojima raspolažemo predstavljaju dva različita alfabeta: glagoljicu i ćirilicu. Ovaj članak nije prikladno mjesto za raspravu oko dva alfabeta, koja otvara brojna pitanja i nudi još veći broj odgovora. Nije jednostavno, a po svoj prilici čak ni moguće, usuglasiti različite teorije barem oko jednog pitanja te rasprave, zato što se argumentacija često temelji ne samo na znanstvenim kriterijima, nego i na filozofskim, teološkim, povijesnim, etničkim, pa čak političkim i ideološkim koncepcijama svojih autora. ${ }^{20}$

Većina znanstvenika uglavnom se slaže da je pismo koje je Konstantin stvorio za kršćane u Moravskoj bila „glagoljica““. ${ }^{21}$ Bilo je različitih pokušaja povezivanja

18 Vita Constantini XIV, 14 kaže samo da je Konstantin „počeo pisati“ (ne prevoditi, iako nije sasvim jasno o čemu je zapravo riječ) beseda evanhel'ska (doslovno „evanđeoski govor“), što bi se moglo razumjeti kao „evanđeosku homiliju“.

19 Taj spis dobio je različite nazive u raznim izdanjima. Najstariji rukopis potječe iz Bugarske i datiran je 1348. godine. Izdanje Džambeluke-Kossove, koje je prvo kritičko izdanje jednog staroslavenskog teksta, nabraja 83 rukopisa (Džambeluka-Kossova, 1980).

20 Kao primjer može se navesti članak Barbare Lomagistro (2004), u kojem pokazuje kako su često znanstveni kriteriji iskrivljeni, pa čak i poreknuti, da bi se stvorili novi, koji trebaju dokazati teze svojih autora.

21 Zahvaljujući jednoj srednjovjekovnoj legendi koja je pripisala glagoljičko pismo sv. Jeronimu (342.-429.), glagoljica je bila poznata kao „pismo svetog Jeronima“. »Sve do kraja XVIII. stoljeća prevladavala je jedna čudna, iako veoma rasprostranjena, opinija, da glagoljica, koja se upotrebljavala u Dalmaciji i Istri te na ostrvima Hrvatske obale, zajedno sa prijevodom Svetoga pisma, potječe od čuvenog Crkvenog oca svetoga Jeronima. Znajući ga kao autora latinske Vulgate, pretpostavljajući da kao urođenik Dalmacije je bio Slaven, točnije Hrvat, slavenska mjesna inteligencija u Dalmaciji, veoma brzo mu je pripisala stvaranje glagoljice, možda s namjerom obraniti kao pismo tako i liturgiju na slavenskom jezikom pred progonima i zabranama od strane Rimske jerarhije, apelirajući na autoritet sv. Jeronima kako bi mogli sačuvati svoje obrede, koji su naslijedili od grka Ćirila i Metoda. Ne znamo tko je prvi rasprostranio ovu tradiciju, neutemeljenu sa znanstvene točke gledišta, o očinstvu sv. Jeronima glagoljice i prijevoda Svetoga pisma, no u 1248. ova verzija je već bila poznata papi Inocentiju IV [...]. Mnoga stoljeća ova vjera u Jeronima kao tvorca glagoljice bila je rasprostranjena ne samo u njegovoj domovini, to jest u Dalmaciji i Hrvatskoj nego također na Zapadu i u Rimu, zbog Slavena koji su tamo živjeli... U XIV. stoljeću 
glagoljice s drugim pismima (primjerice starožidovski, sirijski, gotski, etiopski, gruzijski, armenski), no bez nekih posebnih postignuća (Uspenski, 2005, 63). Granstrem pokušava dokazati da je Konstantin izveo glagoljicu iz posebnog te javnosti malo poznatog sustava tahigrafije, no ponajprije iz kriptografije, pa čak i magije, naglašavajući njezin nenaravni karakter (Granstrem, 1955, 304-305). ${ }^{22}$

Još jedna pretpostavka koja naglašava autorstvo glagoljice sv. Konstantina, kao i njezino teološko značenje, potječe od Černohvostova (Kiparsky, 1964, 393 400). On dokazuje da slova glagoljice potječu od najvažnijih sakralnih simbola: križ — simbol Krista, krug — simbol vječnosti i svemogućnosti Boga Oca; trokut — simbol Svetog Trojstva (Tschernochvostoff, 1995, 141-150). ${ }^{23}$ Najproširenija teorija danas među znanstvenicima ${ }^{24}$ teorija je Isaaka Taylora (1881, 191-192) i Vatroslava Jagića $(1883,416)$, prema kojoj je temelj glagoljice grčki kurziv ili, još preciznije, grčki kurziv 9. stoljeća (Metzger, 1977, 402).

Ćirilično pismo, koje se pojavilo nakon glagoljice, prema većemu broju znanstvenika (Lunt, 2001, 15ss; Ševčenko, 1964, 235s; Ščepkin, 1967, 22-24), derivat je glagoljice i grčkog ustavnog pisma uncijale kao što ga nalazimo u liturgijskim tekstovima od 9. do 10. stoljeća. U ćirilično pismo ušla su 24 slova grčkog alfabeta i 12 znakova za zvukove karakteristične za slavenski fonetski sustav, koji su bili izrađeni na temelju glagoljice (Nimčuk, 2004, 251-252; Enciclopedia cattolica, s. v. cirillico, alfabeto; Istrin, 1988, 57-58). To pismo, puno jednostavnije od glagoljice, sastavio je vjerojatno sv. Klement Ohridski u današnjoj jugoistočnoj Makedoniji (Nimčuk, 2004, 251). Preslavski sabor je ujesen 893. ne samo odobrio upotrebu slavenskog jezika u Crkvi, nego je i potvrdio usavršeno ćirilično pismo kao službeno pismo za crkvenu i svjetovnu upotrebu (Vlasto, 1970, 174; Metzger, 1977, 402-403).

Najstariji crkvenoslavenski rukopisi koji sadržavaju biblijske, liturgijske i teološke tekstove napisani su glagoljicom. Treba ipak primijetiti da nijedan rukopis ne može biti prihvaćen kao svjedočanstvo slavenskog jezika sv. Ćirila i Metoda jer i najstariji imaju jezične razlike koje ukazuju na njihovo različito podrijetlo (Metzger, 1977, 403). Najstariji glagoljaški rukopis potječe s kraja 9. i početka 10. stoljeća. Riječ je o Kijevskim listićima ili Kijevskom misalu. Iz 11. stoljeća potječu Codex Zographensis, Codex Marianus i Codex Assemanius, a najstariji ćirilični rukopisi su Savina knjiga i Codex Suprasliensis.

hrvatski glagoljaški monasi ponijeli su ovu tradiciju Česima te je također imperator Karl IV. njima povjerovao« (Jagić, 1911, 51-52).

22 Za Granstrem izvještačenost glagoljice također je razlog manjka njezine životne snage, izražena ograničenim zemljovidom i činjenicom da nije ostavila nikakva traga u bugarskoj literaturi i u literaturi drevne Rus' (Granstrem, 1955, 302-303, 306). Karski smatra glagoljicu kriptografskim ćiriličnim pismom (Karski, 1979, 356, 361-362).

23 Uspenski, iako tvrdi da nije moguće ustvrditi tu tezu, zato što je apriorna, sa svoje strane pokušava dokazati da su ključno značenje u stvaranju ćirilice imale Kristove riječi: »Ja sam Alfa i Omega, Početak i Kraj«. Analizirajući „simetrična“ slova glagoljice, skraćenice svetih imena, način pisanja i naziv slova $a z$, autor dolazi do zaključka da je glagoljica ideografski izražaj Svetog pisma (Uspenski, 2005, 63-77).

24 Žubrinić u svojem istraživanju govori o 42 teorije (Žubrinić, 1996, 14-23). 


\subsection{Korpus Ćirilo-Metodova prijevoda}

Nije moguće s točnošću odrediti koje su knjige Svetoga pisma preveli sv. Ćiril i Metod. Vita Methodii (XV) izvještava da su »dvojica braće preveli zajedno Psaltir i Evanđelje zajedno sa knjigom Apostola i izabrane činove bogoslužja«. Čak ako riječ „Evanđelje“ možemo razumjeti kao „četiri evanđelja“ ili kao „lekcionar“ (Metzger, 1977, 403), ${ }^{25}$ ipak se zbog povezanosti s knjigom Apostola i Psaltirom — najvažnijom „liturgijskom knjigom“ istočnog bogoslužja jer svaki liturgijski čin predviđa čitanja psalama (psalmodiju) — čini najvjerojatnijim da je riječ o evanđelistaru. Osim toga, još jedan argument za evanđelistar dolazi iz Vita Constantini (XVI, 14) gdje se izričito spominje da je Konstantin počeo prevoditi Evanđelje od prvih redaka evanđelja po Ivanu, s kojima ustvari i počinje bizantski evanđelistar. ${ }^{26}$

Poslije smrti Konstantina u Rimu, Metod uz pomoću dvojice ili trojice ${ }^{27}$ svećenika brzopisaca, prema svjedočenju Vita Methodii (XV) „brzo i potpuno“ preveo je sve biblijske knjige, osim knjiga Makabejcima ${ }^{28} \mathrm{~s}$ grčkog na crkvenoslavenski. Sav posao bio je ostvaren u razdoblju od osam mjeseci: ${ }^{29}$ počeo je u ožujku, a završio 26. listopada 884. godine. Prolog u Teologiju Ivana Egzarha [Ivana Damašćanina] ${ }^{30}$ naprotiv tvrdi da je Metod, poslije smrti brata Ćirila, kao nadbiskup na katedri sv. Andronika u Smirni (danas Sremska Mitrovica), za vrijeme svojeg boravka u Moravskoj »preveo ${ }^{31}$ svih 60 kanonskih knjiga s grčkog na slavenski«.32

25 Iako riječ „evanđelje“ može značiti kako „četiri evanđelja“ tako i liturgijsku knjigu koja sadržava tekst svih četiriju evanđelja, tj. lekcionar, ne bih se složio sa Metzgerom da se ovdje riječ „evanđelje“ nalazi u dvoznačnom kontekstu, jer je doista riječ o jasnom liturgijskom kontekstu.

26 Tekst Ivanova prologa (Iv 1,1-18) u crkvama bizantsko-slavenskog obreda čita se na Božanskoj Liturgiji na Uskrs. Osim toga, primjerice u Ukrajinskoj grkokatoličkoj crkvi postoji običaj čitati to evanđelje na različitim jezicima: grčkom, latinskom, crkvenoslavenskom, ukrajinskom, a često se dodaje i jezik u upotrebi na teritoriju gdje živi zajednica: engleski, njemački, francuski, hrvatski i dr., redak za retkom.

27 Tekst govori o dvojici svećenika. No, kao što je primijetio Mathiesen, „dva“ ne odgovara gramatičkoj formi „pisaca“, koja bi trebala biti dual, a ne množina, kao u tekstu. Mathiesen to objašnjava različitom numeričkom vrijednošću 8 u glagoljici (odgovara broju 2) i u ćirilici (odgovara broju 3) (Mathiesen, 1967, 51-53).

28 U vezi s knjigama Makabejcima vrijedi skrenuti pažnju na to da grčka rukopisna tradicija ne poznaje kodekse koji bi sadržavali samo knjige Makabejcima. Te knjige zapravo sačinjavaju dio kodeksa koji obuhvaćaju knjige Ljetopisa, Prvu i drugu knjigu Ezre te knjige Estere, Tobije i Judite. Budući da nam je nepoznat ikakav prijevod tih knjiga iz vremena sv. Ćirila i Metoda, možemo zaključiti da se izraz „osim Makabejaca“ odnosi na sve knjige te zbirke.

29 U Vita Methodii nalazimo doslovno „šest mjeseci“. No dovoljno je napraviti najjednostavniji izračun kako bi se vidjelo da od ožujka sve do listopada ima osam, a ne šest mjeseci. I u tom slučaju glagoljičko slovo „ళ “ prepisano je ne sa svojom numeričkom vrijednošću 8, koju ima u glagoljici, nego sa 6 - numerička vrijednost slova , $\mathbf{\zeta}(\mathbf{s}) “ \mathrm{u}$ ćirilici.

30 Objavio ju je prvi put 1824. Kalajdovič na temelju jednog rukopisa s početka 12. stoljeća (Kalajdovič, 1824, 129-133).

31 Treba uzeti u obzir to da je cijela serija biblijskih knjiga (Evanđelje Aprakos, Apostol i Psaltir) bila prevedena prije misije u Moravskoj. Osim toga, velik broj tekstova prevedenih iz Staroga zavjeta nalazio se u Paramijniku. Tako da je veći dio prijevoda već bio gotov te je Metodu ostalo samo da završi taj posao (Uhanova, 1998, 89-90).

32 Pregled povijesti istraživanja o formiranju korpusa prijevoda sv. Ćirila i Metoda se nalazi u: Mihajlov, 1912, koji je u velikoj mjeri preuzeo i ažurirao Curkan (2001, 105-140). 
U svakom slučaju, taj prijevod je izgubljen, »što i nije nešto neobično, uzimajući u obzir da je postojao jedan, najviše dva, primjerka, u svoj toj zbrci koja je nastala poslije smrti Metoda «(Vlasto, 1970, 78). Bez svake sumnje radile su se kopije Psaltira i većeg dijela knjiga Novog zavjeta (Otkrivenje, koje ne ulazi u bizantski lekcionar, nije bilo prevedeno). Što se tiče Starog zavjeta, zbog veoma malog broja tekstova koji se koriste u liturgiji (parimejnik), ne moramo biti iznenađeni što je kompletnu kolekciju biblijskih knjiga na crkvenoslavenskom jeziku trebalo čekati do posljednjeg desetljeća 15. stoljeća ili čak do 1581., kada prema riječima Rafajila Turkonjaka — »s izdavanjem Ostroške Biblije se pojavio [prvi put, u potpunosti] slavenski kanon« Svetoga pisma (Turkonjak, 2005, 94).

\section{3. „Sakralnost“ Cirilo-Metodova prijevoda}

Danas crkvenoslavenski nije više živi jezik (kao, što izgleda, nikada nije ni bio) niti je razumljiv većini vjernika. Smatra ga se, dakle, »mrtvim jezikom, u upotrebi samo u liturgiji« (Metzger, 1977, 404), ne samo zbog toga što ima sve manje vlastite literarne produkcije, nego i zbog manjka unutrašnjeg razvitka. Neke istočne crkve (no pogotovo one zapadne) slavenskog korijena upotrebljavaju danas u liturgiji svoj nacionalni jezik, dok druge ustrajavaju na upotrebi crkvenoslavenskog, osim u biblijskim čitanjima i homilijama. U nekim crkvama, uvijek slavenskog podrijetla (primjerice Ukrajinska grkokatolička crkva, Križevačka eparhija, Rusinska grkokatolička crkva), crkvenoslavenski je ostao uz nacionalni jezik i dalje u upotrebi. Taj „liturgijski bilingvizam“ uzrokovan je često manjkom prijevoda liturgijskih tekstova na nacionalni jezik, no argumentira se težnjom vjernosti svojoj tradiciji ili „osjećajem svetosti“ liturgijskog čina, koji čovjeka čini sudionikom Otajstva. ${ }^{33}$ Dakle, jeziku, pa čak nekim izrazima ili slovima, prepisuje se uloga „konzervatora tradicije“, a isto tako i „posvetitelja stvarnosti“ (dovoljno je samo pomisliti na „neprevodivost“ nekih izraza, tj. na „nemogućnost“ izražavanja nekih crkvenoslavenskih pojmova suvremenim jezikom).

Odakle potječe i kako se formirao taj „konzervativan“ i „sakralni“ smisao crkvenoslavenskog jezika? »Prijelaz od poganstva na kršćanstvo na Zapadu je popraćeno veoma bogatom grčko-latinskom tradicijom s kojom kršćanstvo mora računati. [...] Slavensko poganstvo je, naprotiv, s pismene točke gledišta sasvim nijemo « (Pachlovska, 1998, 217). To znači da je slavenska literatura tijesno povezana s „novom vjerom“, s kršćanstvom. Nastavlja Pachlovska: »Nova vjera se identificira potpuno i u svemu s Knjigom zbog toga što je pismo direktna posljedica kristijanizacije. Sam alfabet postaje znak neke više istine. [...] Knjiga i Vjera su dakle jedna nerazdjeljiva cjelina. Naučiti čitati i pisati jednako je što i upoznati Boga« (Pachlovska, 1998, 218). O „svetosti“ crkvenoslavenskog jezika izrazio se još u dalekom 9. stoljeću već spomenuti Črnorizac Hrabar, koji, odbacujući herezu „triju jezika“, dodaje ustvari još jedan „sveti“ jezik: crkvenoslavenski. Uspoređujući početak grčkog pisma, koje se razvijalo mnoga

33 Iako bi mogla biti riječ o „duhovnoj lijenosti“ kojoj je lakše ostati opčinjenom nedokučivošću misterija, nego odgovarati na izazove svakodnevnice. 
stoljeća i prijevod Septuaginte (LXX), Črnorizac Hrabar piše: »A za Slavene jedan jedini Sveti Konstantin, nazvan Ćiril, je stvorio pismo i preveo knjige u par godina; a oni u mnogo i u različitim godinama: sedam ih je stvorilo pismo, a sedamdeset napravilo prijevod « (Lavrov, 1930, 163-164). I zaključuje: »Zato su slavenska slova svetija [i dostojnija], jer ih je stvorio sveti čovjek, dok su grčka slova stvorili Grci pogani« (Lavrov, 1930, 164). To znači da su sveti ne samo crkvenoslavenski jezik ili prijevod Svetog pisma na crkvenoslavenski, nego su i sama slova bila sveta i nositelji istine. Komentirajući jedan izraz sv. Ćirila iz Vita Constantini (XIV): »Tko može pisati propovijed na vodi? I zadobiti heretičko ime«, Uspenski ga tumači drugačije od ostalih: »Bez pisma nije moguće propovijedati kršćanstvo, no ako izmisliš pismo, smatrat će te heretikom! «34 i dodaje da se taj izraz može odnositi na prijevod i na [slavenska] slova, no u tom slučaju, uzimajući u obzir kontekst, odnosi se na slova (Uspenski, 2005, 74).

\section{Zaključak}

Moramo dakle biti svjesni te sakralnosti crkvenoslavenskog jezika i svetosti čak njegovih slova, koje doživljavaju mnogi vjernici od početka njegova postojanja, kako bismo mogli ne samo suditi, nego i razumjeti brzopisce, urednike, izdavače i mentore crkvenoslavenskih rukopisa i knjiga, a također istraživače, znanstvenike, autore i njihova djela. Zapravo, taj osjećaj sakralnosti crkvenoslavenskog jezika sasvim je razumljiv jer, zahvaljujući prijevodu Svetoga pisma i bogoslužjima na crkvenoslavenskom, milijuni kršćana stoljećima su doživljavali susret s Bogom, slušali njegovu Riječ i primali njegov blagoslov za sebe, svoju obitelj, svoj narod. Danas se crkvenoslavenski jezik sve manje i manje koristi u Crkvi, sve manji broj vjernika se moli na njemu, a još manji ga uopće razumije. A vjernici i dalje podižu svoje molitve Gospodinu »na svojem materinskom jeziku « te čuju kako se »njihovim jezicima razglašuju veličanstvena djela Božja « (usp. Dj 2,5-11). No povijest prijevoda Svetog pisma na crkvenoslavenski jezik ne prestaje i dalje prisjećati na pravi smisao razumljivog evanđeoskog navještaja — izazvati pitanje kod slušača: »Što nam je činiti? « (Dj 2,37), kako bi se dao pravi odgovor: »Obratite se i svatko od vas neka se krsti u ime Isusa Krista da vam se oproste grijesi i primit ćete dar, Duha Svetoga« (Dj 2,38). U svakom slučaju, crkvenoslavenski prijevod Svetog pisma u svoje je vrijeme to ostvario, zahvaljujući ponajprije djelovanju slavenskih prosvjetitelja sv. Ćirila i Metoda. To nas vodi zaključku da biblijski prijevod nije samo lingvistička činjenica, pa ni samo povijesna ili kulturološka. Prijevod Svetog pisma je ponajprije „teološki čin“, koji traži od prevoditelja ne samo znanje jezika, pa čak i egzegeze, nego i svetost života prevoditelja, zadaća kojeg je prevesti nerazumljivi tekst u riječ koja zbori. Sveti su Ćiril i Metod „progovorili“" ne samo slavenski, nego ponajprije je-

34 »Ako propovijed kršćanstva ne bude utvrđena na Pismu... bit će pogrešno interpretirana te će voditi herezi« (Dujčev, 1981, 148-150). »Ako Ćiril stvori slavensko pismo, moći će biti optužen za herezu od sljedbenika doktrine triju jezika « (Auty, 1971, 43). 
zikom vjere i svetosti života, posvjedočivši na taj način pouzdanost svojeg prijevoda Svetog pisma. Zato njihov prijevod, iako jezično zastarjeli i sve teže razumljiv za čitatelje, ostaje načelno vrijedan za prevoditelje sve do suvremenih dana.

\section{Literatura:}

Auty, Robert (1971). Old and new ideas on the sources of the glagolitic alphabet. U: Konstantin-Kiril Filosof: Dokladi ot simpoziuma, posveten na 1100-godishninata ot sm'rtta $m u$ (str. 41-44). Sofija: Bulgarska akademiia na naukite.

Bajsić, Vjekoslav (ur.) (1985). Dokumenti o sv. Ćirilu i Metodu. Zagreb: Kršćanska sadašnjost.

Birnbaum, Henrik (1997-1999). Some remaining puzzles in Cyrillo-Methodian studies. Slovo, 47-49. 7-32.

Bratulić, Josip (1985). Žitja Konstantina Ćirila i Metodija i druga vrela. Zagreb: Kršćanska sadašnjost.

Bratulić, Josip (1991). Biblija u Hrvata: Ćirilometodska Biblija i njena sudbina među Hrvatima. Bogoslovska smotra, 61, 1-2, 88-92.

Černih, Pavel Ja. (1951). Язык и письмо. U: История культуры древней Руси, 2 (str. 114-138). Москва - Ленинград: Издательство Академии Наук СССР.

Curkan, Roman (2001). Славянский перевод Библии. Происхождение, история текста и важнейшие издания. Санкт-Петербург: Издательский дом „Коло“ - Издательскоторговий дом „Летний сад“.

Damjanović, Stjepan (2013). Jedanaest i pol stoljeća nezaborava. Croatica et Slavica Iadertina, 9, 1, 39-49.

Damjanović, Stjepan (2015). Tisućljetno hrvatsko glagoljaštvo i njegovi ćirilometodski korijeni. Radovi Zavoda za hrvatsku povijest Filozofskoga fakulteta Sveučilišta u Zagrebu, 47, 1, 39-59.

Devlić, Radovan Domagoj; Kordej, Igor; Horvatić, Dubravko; Lacko, Michal (1985). Ćiril i Metod: Slavenski apostoli i prosvjetitelji: Strip s komentarom. Zagreb: Kršćanska sadašnjost.

Dujčev, Ivan Simeonov (1981). Проучвания върху средновековната българска история и култура. София: Наука и изкуство.

Dvornik, Francis (1970). Byzantine Missions Among the Slavs: SS. Constantine-Cyril and Methodius. New Brunswick: Rutgers University Press.

Džambeluka-Kossova, Alda (ur.) (1980). Черноризеи Храбър: О писменехь (Studia Historica et Filologica, Sectio Slavica), Edizione critica. Софиа: Изд-Во На Българската Академия На Науките.

Enciclopedia cattolica, III. Città del Vaticano: 1949, 1715. (s. v. Cirillico, Alfabeto)

Fućak, Marijan Jerko (1991). Prijevodi Biblije na hrvatski jezik. Bogoslovska smotra, 61, 1-2, 93-98.

Georgiev, Emil (1966). За началото на българската и славянската писменост. Език и литература, 22, 1, 64.

Gorski, Aleksandar V. (1843). О свв. Кирилле и Мефодии. Москвитянин, 6, 405-434.

Grabar, Biserka (1986). Ćirilometodski i staroslavenski prijevodi u hrvatskoglagoljskim prijepisima. Slovo, 36, 87-94.

Granstrem, Evgenija Eduardovna (1955). О происхождении глаголической азбуки. U: Д. С. Лихачев (ur.), Труды отдела древнорусской литературы Института русской литературы, 11 (str. 300-313). Москва - Ленинград: Изд-во Академии наук СССР. 
Grivec, Franc (1985). Sveti Ćiril i Metod — slavenski blagovjesnici. Zagreb: Kršćanska sadašnjost.

Grivec, Franciscus; Tomšić, Franciscus (1960). Constantinus et Methodius Thessalonicenses: Fontes. Radovi Staroslavenskog instituta, 4, 13-276.

Iljinski, Grigori A. (1924). Один эпизод из корсунского периода жизни Константина Философа. Slavia, 3, 1, 64.

Istrin, Viktor A. (21988). 1100 лет славянской азбуки. Москва: Наука.

Ivanova, Tatjana A. (1969). Еще раз о русских письменах. К 1100-летию со дня смерти Константина-Кирилла. Советское славяноведение, 4, 72-75.

Jagić, Vatroslav (1883). Quattuor Evangeliorum versionis palaeoslovenicae Codex Marianus Glagoliticus. Berlin: Weidmann. [Prema pretisku: Graz: Akademische Druck, 1960.]

Jagić, Vatroslav (1895). Рассуждения южнославянской и русской старины о церковнославянском языке. СПб.: Типографія Императорской Академіи Наукъ.

Jagić, Vatroslav (1911). Глаголическое письмо. U: Игнатий Викентьевич Ягичъ (ur.), Энцииклопедія славянской филологіи (str. 51-257). Санкт Петербург: Типографія Императорской Академіи Наукъ.

Jakobson, Roman (1939-1944). Saint Constantin et la langue syriaque. Annuaire de l'institut de philologie et d' histoire orientales et slaves, 7, 181-186.

Jambrek, Stanko (2007). Biblija u Hrvata: Prevođenje, tiskanje i širenje Biblije u kontekstu naviještanja evanđelja. Kairos, 1, 1, 61-90.

Jambrek, Stanko; Knežević, Ruben (2007). Kronološki pregled objavljenih potpunih i djelomičnih prijevoda Biblije na hrvatski jezik. Kairos, 1, 1, 137-156.

Jungerov, Pavel A. (1902). Общее историко-критическое введение в священные ветхозаветные книги. Казань: Типо-литографія Императорскаго Университета.

Kalajdovič, Konstantin (1824). Іоаннъ Ексархъ Болгарскій: изсльдованіе, объясняющее исторію словенскаго языка и литтературы IX и Х стольтій. Москва: въ типографіи Семена Селивановскаго.

Karski, Evfimi F. (1979). Славянская кирилловская палеография. Москва: Издательство „Наука“.

Kiparsky, Valentin (1964). Tschernochvostoffs Theorie über den Ursprung des glagolitischen Alphabets. U: Manfred Hellmann, Reinhold Olesch, Bernhard Stasiewski i Franz Zagiba (ur.), Cyrillo-Methodiana: Zur Frühgeschichte des Christentums bei den Slaven 863-1963 (str. 393-400). Köln — Graz: Böhlau Verlag.

Lacko, Michal (1985-1986). [Komentari uz strip.] U: Radovan Domagoj Devlić; Igor Kordej; Dubravko Horvatić; Michal Lacko, Ćiril i Metod: Slavenski apostoli i prosvjetitelji: Strip s komentarom (br. 1, 14-20; br. 2, 12-15, 26-31; r. 3, 16-19, 28-31; br. 4, 13-20, 29-31; br. 5, 19-14, 25-31). Zagreb: Kršćanska sadašnjost.

Lavrov, Petr A. (1930). Материаль по истории возникновения древнейшей славянской письменности. Ленинград: Издательство Академии Наук СССР.

Lomagistro, Barbara (2004). Paleografia e ideologia. Studi Slavistici, 1, 127-138.

Lukić, Milica (2011). Strossmayerov projekt obnove Ćirilometodske baštine. Anali Zavoda za znanstveni i umjetnički rad u Osijeku, 27, 67-96.

Lunt, Horace G. (1964). The Beginning of Written Slavic. Slavic Review, 23, 2, 212-219.

Lunt, Horace Gray (2001). Old Church Slavonic grammar. Berlin — New York: Walter de Gruyter.

Mathiesen, Robert (1967). An Emendation to the Vita Methodii XV, I. Zbornik za filologiju i lingvistiku, 10, 51-53. 
Metzger, Bruce M. (1977). The early versions of the New Testament: Their origin, transmission, and limitations. New York: Oxford University Press.

Mihajlov, Aleksandr V. (1912). Опыт изученія текста книги Бытія пророка Моисея въ древне-славянскомъ переводъ, 1: Паремийный текстъ. Варшава: Типографія Варшавскаго Учебнаго Округа.

Nimčuk, Vasil V. (1985). Сказаніє чорноризця Храбра. U: Німчук, Василь В. (ur.), Мовознавство на Україні в XIV - XVII cm. Київ: Наукова думка. URL: http://itopys. org.ua/nimchuk/nim03.htm (14.03.2017.)

Nimčuk, Vasil V. (22004). Кирилиця. U: Українська мова. Енциклопедія (str. 251-252). Київ: Видавництво »Українська енциклопедія« ім. М. П. Бажана.

Pachlovska, Oxana (1998). Civiltà letteraria ucraina. Rim: Carocci.

Šanjek, Franjo (1983). Ćirilometodska baština u Hrvata. Croatica Christiana periodica, 7 , 12, 122-129.

Ščepkin, Vjačislav Nikolaevič (1967). Русская палеография. Москва: Издательство „Наука“.

Ševčenko, Ihor (1964). Three paradoxes of the Cyrillo-Methodian mission. Slavic Review, 23, 220-236.

Štefanić, Vjekoslav (1941). E. Hrvatski prijevod Biblije. U: Hrvatska Enciklopedija: Svezak II: Autonomaši — Boito (s. v. Biblija, str. 490-494). Zagreb: Naklada Hrvatskog izdavalačkog bibliografskog zavoda.

Štefanić, Vjekoslav (1963). Tisuću i sto godina od moravske misije. Slovo, 13, 5-42.

Šuljak, Andrija (1986). Metodova godina: 1100. obljetnica smrti sv. Metoda (885-1985). Croatica Christiana periodica, 10, 17, 181-187.

Taylor, Isaac (1881). Über den Ursprung des glagolitischen Alphabets. Archiv für slavische Philologie, 5, 191-192.

Tschernochvostoff, Georg (1995). Zur Ursprung der Glagolica. Studia Slavica Finlandensia, 12, 141-140.

Turkonjak, Rafajil (2005). Острозька Біблія. Вступи, гравюри, дослідження. Львів: Українське Біблійне Товариство - Благодійний Фонд „Книга“.

Uhanova, Elena Vladimirovna (1998). У истоков славянской письменности. Москва: Издательский Дом „Муравей“.

Uspenski, Boris A. (2005). О происхождении глаголицы. Вопросы языкознания, 1, 63-77.

Vaillant, Andre (1935). Les Lettres russes de la Vie de Constantin. Revue des études Slaves, $15,75-77$.

Vasiliev, Alexander Alexandrovich (1936). The Goths in the Crimea. Cambridge Mass.: The Mediaeval Academy of America.

Vernadsky, George (1943). Ancient Russia. New Haven: Yale University Press.

Vlasto, Alexis P. (1970). The Entry of the Slavs into Christendom: An introduction to the medieval history of the Slavs. Cambridge: Cambridge University Press.

Vojnović, Tadej (2006). Prevođenje cjelovite Biblije u Hrvata od Ćirila i Metoda do prve tiskane Biblije 1831. godine. Anali Zavoda za znanstveni i umjetnički rad u Osijeku, 22, 141-152.

Žubrinić, Darko (1996). Hrvatska glagoljica: Biti pismen — biti svoj. Zagreb: Hrvatsko književno društvo sv. Jeronima (sv. Ćirila i Metoda). 
Saints Cyril and Methodius and the Translation of the Holy Scripture into Old Church Slavonic

Taras Barščevski*

\section{Summary}

Translations come about fundamentally and primarily to enable one who does not understand the language in which the text is written to understand the original text. Biblical texts are not simply texts written in the Old Hebrew (Aramaic) or Ancient Greek languages, but texts containing the Word of God - God's revelation of Himself and of His will that all men be saved. Thus, a translation of the Holy Scripture is not only a translation from one language (ancient and not understandable) to another, but a transmission of Divine Revelation. The translation of Saints Cyril and Methodius achieves both. The article examines existing circumstances and the emergence of the cyrilomethodic translation of the Holy Scripture into Old Church Slavonic, by firstly addressing the reasons - proclamation of the Gospel to the Slavs - but also the difficulties encountered in their translation activities - non-existence of a script and the resistance to liturgical use of the Old Slavonic language. The response of the Slavic apostles to the non-existence of a Slavonic script was to devise the Glagolithic and Cyrillic alphabets, and the right to use them in the liturgy was attained through the translation of not only the Holy Bible but also of numerous liturgical texts. Thus, these accomplishments of the saintly brothers had an effect initially, not only on the development of Christianity among Slavic peoples, but in later centuries often became the reason for holding missionary fervour in abeyance as the „sacredness" of the translation was to be preserved.

Key words: translation of the Holy Scripture, Saints Cyril and Methodius, Old Church Slavonic, Glagolithic alphabet, Cyrillic alphabet, „sacredness" of the translation

* Taras Barščevski, Ph.D., Catholic Faculty of Theology of the University of Zagreb. Address: Vlaška 38, p.p. 432, 10000 Zagreb, Croatia. E-mail: tbarcscevski@kbf.hr 